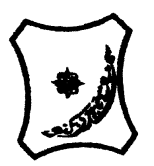

Bayero Journal of Pure and Applied Sciences, 12(2): 1 - 11

Received: March, 2019

Accepted: December, 2019

ISSN $2006-6996$

\title{
PHARMACOGNOSTIC, ELEMENTAL AND ACUTE TOXICITY STUDY OF Fadogia agrestis ROOT
}

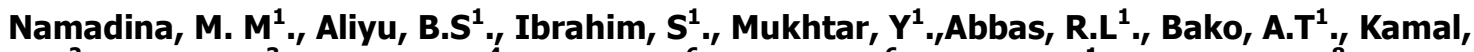
R.M ${ }^{2}$., Sunusi, $\mathbf{U}^{3}$., Muttaka, A $^{4}$, Sanusi, H. $^{6}$, Hafiz, S.S ${ }^{6}$., Aliko, A.A ${ }^{1}$, Adamu, M.M ${ }^{8}$., Umar,

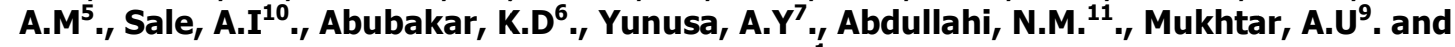
Yakubu, $\mathbf{N}^{1}$

\footnotetext{
${ }^{1}$ Department of Plant Biology, Bayero University, Kano, Nigeria.

${ }^{2}$ Department of Pharmacology, Federal University, Dutse, Jigawa State, Nigeria

${ }^{3}$ Department of Biochemistry, Faculty of Basic Medical Science, Bayero University, Kano

${ }^{4}$ Department of Biochemistry, Federal University Gusau

${ }^{5}$ Department of Remedial and General Studies, Audu Bako Collage of Agriculture, Dambatta

${ }^{6}$ Department of Biological Science, Federal University, Dutsinma

7 Department of Biological Sciences, Federal University Wukari, Taraba State

${ }^{8}$ Department of Integrated Science, Saadatu Rimi Collage of Education, Kumbotso, Kano

${ }^{9}$ Department of Microbiology, Kaduna State University

${ }^{10}$ Department of Biology, Kano University of Science and Technology Wudil

${ }^{11}$ Department of Biology, Saadatu Rimi Collage of Education, Kumbotso

Corresponding author: Hajiyaiyalle@gmail.com - 07035939668
}

ABSTRACT

An aphrodisiac is a type of food or drink that has the effect of making those who eat or drink it more aroused in a sexual way. Aphrodisiacs can be categorized according to their mode of action into three groups: substances that increase libido (i.e. sexual desire, arousal), substances that increase sexual potency (i.e. effectiveness of erection) and substances that increase sexual pleasure. Fadogia agrestis (Schweing. Ex. Hiern), Rubiaceae (Hausa: Bakin gagai; English name: Black aphrodisiac) is an erect shrub 1-3 feets high. Fadogia agrestis is a medicinal plant widely used for its reported antibacterial and aphrodisiac activities. The aim of this work is to carry out pharmacognostic standardization and safety profile on Fadogia agrestis root. Chemomicroscopical, physicochemical, elemental, phytochemical and acute toxicity studies were carried out using standard methods. The results obtained also provided scientific basis for the use of F. agrestis in folklore medicine. Chemomicroscopic characters present include; cellulose cell wall, lignified cell wall, tannins, starch, calcium oxalate and cutin. The physicochemical parameters evaluated include: moisture content (7.0\%), total ash $(10.5 \%)$, water soluble ash (4.1\%), acid insoluble ash (8.33\%), ethanol extractive value (15.0\%), and water extractive value (12.0\%). The quantitative phytochemical analysis showed that alkaloids $(84.0 \mathrm{mg} / \mathrm{g})$ was the highest phytochemical detected in the stem bark while the lowest was saponins $(4.0 \mathrm{mg} / \mathrm{g}) . \angle D_{50}$ of both extracts was above 5000 $\mathrm{mg} / \mathrm{kg}$ and did not cause mortality in all the tested rats. The results of this investigation may be useful for deriving doses that are safe for human consumption medicinally of $F$. agrestis root.

Key words: Fadogia agrestis, quantitative, qualitative, phytochemical, Chemomicroscopical

\section{INTRODUCTION}

Natural products are chemical compounds or substances produced by living organisms; they are found in nature and usually have a pharmacological or biological activity for use in pharmaceutical drug discovery and design.
These products can be considered as such even if they can be prepared by total synthesis. They may be extracted from tissues of terrestrial plants, marine organisms or microorganism fermentation broths. 
BAJOPAS Volume 12 Number 2, December, 2019

A crude (untreated) extract from any one of these sources typically contains novel and structurally diverse chemical compounds. Natural products, including those obtained from plants, animals and minerals have been the basis of treatment of human diseases (Patwardhan et al., 2004; Lahlou, 2013).

History of medicine dates back practically to the existence of human civilization. Historically, the majority of new drugs have been generated from natural products (secondary metabolites) and from compounds derived from natural products (Lahlou, 2013). Recently, there has been a renewed interest in natural product research due to the failure of alternative drug discovery methods to deliver many lead compounds in key therapeutic areas such as immune suppression, anti- invectives, and metabolic diseases. These approved substances are representative of very wide chemical diversity and continue to demonstrate the importance of compounds from natural sources in modern drug discovery efforts (Chin et al., 2006).

Fadogia agrestis Schweinf, family-Rubiaceae (Hausa: Bakin Gagai; English: Black aphrodisiac) is an erect shrub that is 1-3 feet tall. It has tomentellous stems and leaves that are yellow in color. Ethnomedicinal survey of $F$. agrestis reveals a variety of uses such as aphrodisiac in tropical African countries (Yakubu et al., 2005). This plant is used to modify sexual functions, in animals, especially those arising from hypotesteronemia. Phytochemical screening of the aqueous extract of Fadogia agrestis stem and root showed the presence of alkaloids and saponins, while anthraquinones and flavonoids are present in small amount. Saponins have been implicated as possible bioactive agent responsible for the Aphrodisiac effect in Tribulus terrestris extract (Gauthaman et al., 2002). The prolonged ejaculatory latency indicates enhancement of sexual function and suggests an aphrodisiac action male rats were orally dosed with $18 \mathrm{mg} / \mathrm{kg}, 50 \mathrm{mg} / \mathrm{kg}$ and $100 \mathrm{mg} / \mathrm{kg}$ body weight, respectively, of the extract at $24 \mathrm{hr}$ intervals and their sexual behavior parameters and serum testosterone concentrations were evaluated at days 1, 3 and 5 (Yakubo et al., 2005. There was also a significant increase in serum testosterone concentration in all groups of tested animals (Yakubo et al., 2005). So, it may be used to modify impaired sexual functions in animals especially those arising from hypotesteronemia.
MATERIALS AND METHODS Collection and Identification of Plant material

Fadogia agrestis root was collected out in March, 2017 from Babura Local Government Area of Jigawa State and conveyed for identification and authentication at the Herbarium unit of Department of Plant Biology, Bayero University, Kano by a taxonomist in which a voucher's numbers BUKHAN487 was assigned to the plant.

\section{Extraction of Plant Materials}

Dried plant materials $(50 \mathrm{~g})$ were extracted using cold maceration with $500 \mathrm{ml}$ of both distilled water and methanol. The contents were then be filtered using a filter paper (Whatman no.1), the filtrate was concentrated to dryness using water bath which was kept in desiccator.

\section{Chemo-microscopic Studies on the powdered root of Fadogia agrestis}

Powdered sample $(5 \mathrm{~g})$ of plant species was used for this study to detect the presence of cell wall materials and cell inclusions. Finely ground sample of plant was cleared in a test tube containing $70 \%$ chloral hydrate solution. It was then be boiled on a water bath for about thirty minutes to remove obscuring materials. The cleared sample was mounted with dilute glycerol onto a microscope slide. Using various detecting reagents the presence of cell wall materials and cell inclusions was detected in accordance to WHO (2011) guidelines.

\section{Cell wall Materials}

\section{Test for Cellulose}

A drop or two of iodinated zinc chloride was added to the powdered sample and allowed to stand for a few minutes and observed under a microscope. It stained cellulose cell wall blue to blue- violet (WHO, 2011).

\section{Test for Lignin}

The powdered plant material was moistened on a slide with a small volume of phloroglucinol and allowed to stand for about two minutes or until almost dry. A drop of hydrochloric acid was added and viewed under a microscope. Pink stained or cherry red was observed for the presence of lignin (WHO, 2011).

Test for Suberized or Cuticular cell walls

A drop or two of Sudan red was added to the cleared powdered sample and allowed to stand for few minutes and observed under a microscope. Orange red or red colour was observed presence of suberin or cutin on the cell (WHO, 2011).

\section{Test for Gum and Mucilage}

To a small portion of the cleared powdered sample of the plant, a drop of ruthenium red was added. Appearance of pink coloration was considered positive for gums and mucilage (WHO, 2011). 


\section{Cell Inclusions/ Cell Contents Test for Starch grains}

To a small portion of the cleared powder sample of the plant, N/50 iodine was added. Appearance of blue-black or reddish-blue coloration on some grains would be considered positive for starch (WHO, 2011).

Test for Calcium oxalates and Calcium Carbonates

To a small portion of the cleared powdered sample of the plant, $\mathrm{HCl}$ was added, dissolution of crystals in the powdered drug without effervescence was considered positive for calcium oxalate while slow dissolution with effervescence was considered positive for calcium carbonate (WHO, 2011).

\section{Inulin}

A drop of 1-naphthol and that of sulphuric acid was added to the powdered sample and viewed under the microscope. Spherical aggregations of crystals of Inulin turned brownish red and dissolve (WHO, 2011).

\section{Test for Tannins}

To a small portion of the cleared powdered sample of the plant, $5 \%$ ferric chloride solution was added. Appearance of greenish black colour was considered as positive for tannins (WHO, 2011).

\section{Determination of Physicochemical Constants of the powdered root of Fadogia agrestis}

Some physicochemical parameters of the powdered sample of the plant such as moisture content, total ash, acid-insoluble ash, watersoluble ash, alcohol and water extractive values was determined as described in the updated edition of quality control methods for medicinal plant materials (WHO, 2011).

\section{Moisture Content}

This is the quantity of moisture present in a plant material. Moisture content of the powdered sample will be determined by loss on drying method.

$3.0 \mathrm{~g}$ each of the powdered sample was accurately weighed and placed in some clean, dried evaporating dishes of known weights. They were placed in an oven and heated at a temperature of $1050 \mathrm{C}$ for 1 hour, then cooled in a dessicator and re-weighed. Heating and weighing were repeated until a constant weight was obtained. The weight loss on drying was computed following the formula below:

$\begin{array}{lll}\% & \text { Moisture } & \text { content } \\ =\frac{\text { Initial Weight of Powder-Final Weight of Powder }}{\text { Initial Weight of Powder }} & \text { X } 100\end{array}$

\section{Total Ash Value}

$2 \mathrm{~g}$ of powdered plant materials was accurately weighed and placed separately in a crucible of known weight. It was heated gently and the heat gradually increased until it is white indicating the absence of carbon. It was allowed to cool in a desiccator and weighed; this was repeated until a constant weight was obtained. The total ash value was determined as a percentage with the formula below

$$
=\frac{\text { Weight of Residual Ash }}{\text { Original Weight of Powder }} \times 100 \quad \text { Ash Value }
$$

Acid-insoluble ash

This is the residue that remains after boiling the total ash with dilute hydrochloric acid.

This was determined for the powdered plant material. $25 \mathrm{ml}$ of dilute hydrochloric acid was added to the crucible containing ash. It was covered with a watch glass and gently boiled for 5 mins. The watch glass was rinsed with $5 \mathrm{ml}$ of hot water and the liquid added to the crucible. The insoluble matter was collected on an ash less filter-paper and washed with hot water until the filtrate is neutral. The filter-paper containing the insoluble matter was transferred to the original crucible, dried in an oven and ignited to a constant weight. The residue was allowed to cool in a suitable desiccator for 30 minutes and then weighed without delay (Evans, 2002).

The acid-insoluble ash will then be calculated as a percentage for each of the two plants with the formula

$\% \quad$ Acid insoluble Ash $=\frac{\text { Weight of Residual Ash }}{\text { Original Weight of Powder }}$ X 100

\section{Water soluble ash}

To the crucible containing the total ash, $25 \mathrm{ml}$ of water was added and boiled for 5 minutes. The insoluble matter was collected in a sintered glass crucible. It was then be washed with hot water and ignited in a crucible for 15 minutes at $105^{\circ} \mathrm{C}$. The weight of the residue was subtracted from the weight of the total ash. The content of water soluble ash per air dried powdered sample was calculated and recorded (WHO, 2011).

$\% \quad$ Water $\quad$ Soluble Ash
$\frac{\text { Weight of Total Ash-Weight of Residual Ash }}{\text { Original Weight of Powder }} \times 100$

\section{Alcohol-Soluble Extractive Value}

This is the amount of extraction in percentage of a plant sample with alcohol.

$4 \mathrm{~g}$ of each of the plant material was separately weighed in a conical flask. $100 \mathrm{ml}$ of ethanol was added and macerated for 24 hours, during which the mixture was frequently shaken within the first 6hours using a mechanical shaker. It was filtered and $25 \mathrm{ml}$ of the filtrate transferred into an evaporating dish of known weight and evaporated to dryness on a water bath. It was dried to a constant weight, the percentage of alcohol-soluble extractive value was then determined for the plant as 
Alcohol-Soluble Extractive Value (\%) = $\frac{\text { Weight of Residue in } 25 \mathrm{ml} \text { extract } \times 4}{\text { Initial weight of sample }} \times 100$

Water-Soluble Extractive Value

This is the amount of extraction in percentage of a plant sample with water. Same procedure as in alcohol-soluble extractive value was repeated here for the two plants, but solvent for extraction here was water.

Water-Soluble Extractive Value (\%) =

$\frac{\text { Weight of Residue in } 25 \mathrm{ml} \text { extract } \times 4}{\text { Initial weight of sample }} \times 100$

\section{Elemental analysis of Fadogia agrestis powdered root Acid Digestion of the samples}

Powdered plant material $(0.5 \mathrm{~g})$ was weighed into 10 different beakers each of $50 \mathrm{ml}$, to which $2.5 \mathrm{ml}$ of hydrochloric acid $(\mathrm{HCl})$ and $7.5 \mathrm{ml}$ Nitric Acid $\left(\mathrm{HNO}_{3}\right)$ were added to each beaker. The 10 beakers used were placed in an open space for 2 hours and mixture of hydrochloric acid $(\mathrm{HCl})$ and nitric acid $\left(\mathrm{HNO}_{3}\right)$ in 1:1 ratio was added to each beaker. It was kept on a hot plate at $100^{\circ} \mathrm{C}$ $170^{\circ} \mathrm{C}$ for $1-4$ hours. After the contents in beakers is about to dried; $5 \mathrm{ml}$ of Hydrochloric acid $(\mathrm{HCl})$ was added to each beaker and be kept on the hot plate until the entire liquid content in the beakers got evaporated. Then, de-ionized water $(5 \mathrm{ml})$ was added to each beaker and the solutions were poured in sterile bottles and tested for the quantification of the metals. The concentration of $\mathrm{Fe}, \mathrm{Mg}, \mathrm{Zn}, \mathrm{Cu}$ was read using the flame atomic absorption spectrophotometer (FAAS), AA 500 model, Atomic Emission Spectrophotometer, $\mathrm{HACH}$ Spectrophotometry (DR/4200) and Atomic Absorption Spectrophotometer were used for other elements detected The elemental analyses of the plant materialswere carried out in Ahmadu Bello University Zaria, Multi-user Research Laboratory. The mineral elements estimations indicated the amount of macro, trace elements and heavy metals present in the Plant samples. The mineral elements detected include; Zinc ( $\mathrm{Zn})$, Magnesium $(\mathrm{Mg})$, Lead $(\mathrm{Pb})$, Manganese $(\mathrm{Mn})$, Selenium (Se), Copper (Cu), Iron (Fe), Cadmium (Cd), Arsenic, Nickel and these were done by Spectrophotometric methods. Before determining the concentration of any element in the sample, calibration curve of the element in the sample was prepared using prepared standard stock solutions for the elements as reported by AOAC, 2000; 2005; Akpabio and Ikpe (2013).

Qualitative Phytochemical screening of Fadogia agrestis root extracts

The plant extracts (aqueous and methanol) were subjected to phytochemical screening in order to identify the phytochemical constituents of the plant using the method described below.

\section{Tests for carbohydrates}

\section{* Molish's (General) Test for} Carbohydrates:

To $1 \mathrm{ml}$ of the filtrate, $1 \mathrm{ml}$ of Molish's reagent was added in a test tube, followed by $1 \mathrm{ml}$ of concentrated sulphuric acid down the test tube to form a lower layer. A reddish colour at the interfacial ring indicates the presence of carbohydrate (Evans, 2009).

\section{Tests for Saponin}

\section{* Frothing test}

About $10 \mathrm{ml}$ of distilled water was added to a portion of the extract and was shaken vigorously for 30 seconds. The tube was allowed to stand in a vertical position and was observed for 30 mins. A honeycomb froth that persists for $10-15 \mathrm{mins}$ indicates presence of saponins (Evans, 2009).

\section{Test for Flavonoids}

\section{* Shinoda Test}

A portion of the extract was dissolved in $1-2 \mathrm{ml}$ of $50 \%$ methanol in the heat metallic magnesium chips and few drops of concentrated hydrochloric acid were added. Appearance of red color indicates presence of flavonoids (Evan, 2009).

\section{Test for Alkaloid}

\section{* Wagner's Test}

Few drops of Wagner's reagents were added to a portion of the extract, whitish precipitate indicates the presence of alkaloid (Evans, 2009).

\section{Test for Steroid and Triterpenes}

* Liebermann-Burchard's test

To a portion of the extract, equal volume of acetic acid anhydride was added and mixed gently. $1 \mathrm{ml}$ of concentrated sulphuric acid was added down the side of the test tube to form a lower layer. A colour change observed immediately and later indicates the presence of steroid and triterpenes. Red, pink or purple colour indicates the presence of Triterpenes while blue or blue green indicates steroids (Evans, 2009).

\section{Test for Cardiac Glycoside \\ * Kella-killiani's test}

A portion of the extract was dissolved in $1 \mathrm{ml}$ of glacial acetic acid containing traces of ferric chloride solution. This was then transferred into a dry test tube and $1 \mathrm{ml}$ of concentrated sulphuric acid was added down the side of the test tube to form a lower layer at the bottom. Observed carefully at the interphase for purplebrown ring, this indicates the presence of deoxy sugars and pale green colour in the upper acetic acid layer indicates the presence of cardiac glycosides (Evans, 2009). 
BAJOPAS Volume 12 Number 2, December, 2019

Test for Tannins

* Ferric chloride test

To a portion of the extract, 3-5 drops of ferric chloride was added. A greenish black precipitate indicates presence of condensed tannins while hydrolysable tannins give a blue or brownish blue precipitate (Evans, 2009).

\section{Test for Anthraquinones}

* Bontrager's test

To a portion of the extract in a dry test tube, $5 \mathrm{ml}$ of chloroform was added and shaken for at least 5 mins. This was filtered and the filtrate shaken with equal volume of $10 \%$ ammonium solution, bright pink colour in the aqueous upper layer indicates the presence of free anthraquinones (Evans, 2009).

Quantitative Phytochemical screening of the methanol extract of Fadogia agrestis root

\section{Alkaloid Determination using Haborne} (1973) Method

About $5 \mathrm{~g}$ of the sample was weighed into a $250 \mathrm{ml}$ beaker and $200 \mathrm{ml}$ of $10 \%$ acetic acid in ethanol were added and covered and allowed to stand for 4hours. This was filtered and the extract is concentrated on a water bath to one quarter of the original volume. Concentrated ammonium hydroxide was added drop wise to the extract until the precipitation is completed. The whole solution was allowed to settle and the precipitates were collected and wash with dilute ammonium hydroxide and then filtered. The residue is the alkaloid, which was dried and weighed.

Flavanoid Determination by the Method of Bohm and Kocipal - Abyazan (1994)

About $10 \mathrm{~g}$ of the plant sample was extracted repeatedly with $100 \mathrm{ml}$ of $80 \%$ aqueous methanol at room temperature. The whole solution was filtered through Whatman filter upper No. 42 (125mm). The filtrate was later be transferred into a crucible and evaporated into dryness over a water bath and weighed to a constant weight.

\section{Saponin Determination}

The method of Obadoni and Ochuko (2001) was used. Out of the grinded samples $10 \mathrm{~g}$ was weighed for each and put into a conical flask and $100 \mathrm{ml}$ of $20 \%$ aqueous ethanol were added. The samples were heated over a hot water bath for 4hours with continuous stirring at about $55^{\circ} \mathrm{C}$. The mixture was filtered and the residue re-extracted with another $200 \mathrm{ml}, 200 \%$ ethanol. The combined extracts were reduced to $40 \mathrm{ml}$ over water bath at about $90^{\circ} \mathrm{C}$. The concentrate was transferred into a $250 \mathrm{ml}$ separatory funnel and $20 \mathrm{ml}$ of diethyl ether was added and shaken vigorously. The aqueous layer was recovered while the ether layer was discarded. The purification process was repeated and $60 \mathrm{ml}$ of $\mathrm{n}$ - butanol was added. The combined n-butanol extracts were washed twice with $10 \mathrm{ml}$ of $5 \%$ aqueous sodium chloride. The remaining solution was heated in a water bath. After evaporation the samples were dried in the oven to a constant weight; the saponin content was calculated as percentage.

Tannin Determination by Van-Burden and Robinson (1981) Method

About 500mg of each sample was weighed into a $50 \mathrm{ml}$ plastic bottle and $50 \mathrm{ml}$ of distilled water was added and shaken for 1hour on a mechanical shaker. This was filtered into a $50 \mathrm{ml}$ volumetric flask and made up of the mark. Then $5 \mathrm{ml}$ of the filtrate was pipetted out into a test tube and mixed with $2 \mathrm{ml}$ of $0.1 \mathrm{M} \mathrm{FeCl}_{3}$ in $0.1 \mathrm{M}$ $\mathrm{HCl}$ and $0.008 \mathrm{M}$ potassium ferrocyanide. The absorbance was measure at $120 \mathrm{~mm}$ within 10min.

Determination of Total Phenols by Spectrophotometric Method

The fat free sample was boiled with $50 \mathrm{ml}$ of ether for the extraction of the phenolic component for 15minutes. About $5 \mathrm{ml}$ of the extract was pipetted into a $50 \mathrm{ml}$ flask, and then $10 \mathrm{ml}$ of distilled water was added. About $2 \mathrm{ml}$ of ammonium hydroxide solution and $5 \mathrm{ml}$ of concentrated amyl alcohol were added also. The sample was made up to mark and allowed to react for about 30 minutes for colour development. This was measured at $505 \mathrm{~nm}$.

Acute toxicity studies of aqueous extract of Fadogia agrestis root

\section{Lethal Dose $\left(L D_{50}\right)$ Determination}

This is the determination of the lethal dose known as $L D_{50}$. The method of Lorke (1983) was employed. The phase I involved the oral administration of three different doses of 10 , 100 and $1,000 \mathrm{mg} / \mathrm{kg}$ of the crude extract, to three different groups of three adult wister albino rats. In a fourth group, three adult male wister albino rats were administered with equivalent/volume of distilled water to serve as control. All the animals were orally administered the extract using a curved needle to which a catheter had been fixed. The animals were monitored closely every 30 minutes for the first 3 hours after administration of the crude extract and hourly for the next 6hours for any adverse effects. Then the animals were left for 72 hours for further observation.

When no death occurred, the phase II was employed, only one animal was required in each group. Groups 1-4, animals were orally given $1,500,2,200,3250$ and 5,000mg/kg dose levels of the crude extract. All the animals were left for observation as in stage one. 
BAJOPAS Volume 12 Number 2, December, 2019 RESULTS

Chemo-microscopical studies on root of Fadogia agrestis was found to have cellulose cell wall, lignin, calcium oxalate crystals, tannins, starch and calcium carbonate, gum and mucilage (Table 1). The average moisture contents in the powdered plant material using loss on drying method was calculated to be $7.0 \%$, the total ash was $10.5 \%$ while acid insoluble and water soluble were $4.1 \%$ and $8.33 \%$ respectively. The alcohol and water extractives values were obtained to be $15.0 \%$ and $12.0 \%$ respectively (Table 2).

Table 1: Chemomicroscopical studies of Fadogia agrestis powdered root

\begin{tabular}{lc}
\hline Constituents & Inference \\
\hline Starch & + \\
Gum and Mucilage & + \\
Cellulose cell walls & + \\
Lignin & + \\
Aleurone grain & + \\
Calcium oxalate crystals & + \\
Calcium carbonate & - \\
Suberized/Cuticular cell wall & + \\
Inulin & + \\
\hline
\end{tabular}

Key: + Present, - Absent

Table 2: Physicochemical Constants of Fadogia agrestis powdered root

\begin{tabular}{lc}
\hline Parameters & Values (\%w/w) \pm SEM* \\
\hline Moisture content & $7.00 \pm 0.00$ \\
Ash content & $10.50 \pm 0.29$ \\
Acid insoluble ash & $4.10 \pm 0.26$ \\
Water soluble ash & $8.33 \pm 0.88$ \\
Water extractive value & $12.00 \pm 0.58$ \\
Ethanol extractive vale & $15.00 \pm 0.33$ \\
\hline
\end{tabular}

*Average values are of three determinations in Mean \pm Standard Error Mean

Trace metals which include $\mathrm{Fe}, \mathrm{Mn}$ and $\mathrm{Ni}$ detected in Fadogia agrestis were below the FAO/WHO permissible limit for edible plants. While others, $\mathrm{Pb}, \mathrm{Zn}, \mathrm{Cd}$ and $\mathrm{Cu}$ were found to be within the safety limit.

Table 3: Elemental analysis of Fadogia agrestis powdered root

\begin{tabular}{lll}
\hline Elements & Concentration $(\mathrm{ppm})$ & FAO/WHO $(1984)$ limit* $(\mathrm{ppm})$ \\
\hline Iron(Fe) & 11.737 & 20.00 \\
Copper $(\mathrm{Cu})$ & 0.116 & 3.00 \\
Lead $(\mathrm{Pb})$ & 0.373 & 0.43 \\
Zinc $(\mathrm{Zn})$ & 0.544 & 27.40 \\
Nickel $(\mathrm{Ni})$ & 0.223 & 1.63 \\
Manganese (Mn) & 0.977 & 2.00 \\
Aluminum (Al) & 14.302 & - \\
Cadmium (Cd) & -0.007 & 0.21 \\
Selenium (Se) & 0.101 & - \\
Chromium (Cr) & 0.021 & - \\
Arsenic (As) & 0.159 & - \\
\hline
\end{tabular}

Phytochemical screening of aqueous and methanol extracts revealed the presence of alkaloid, flavonoids, glycoside, triterpenes and tannins, steroid, saponins, phenols, anthraquinones and carbohydrate (Table 4). 
BAJOPAS Volume 12 Number 2, December, 2019

Table 4. Qualitative Phytochemical screening of aqueous and methanolic root extract of Fadogia agrestis root

\begin{tabular}{lcc}
\hline Metabolite & \multicolumn{2}{c}{ Inference } \\
\hline \\
Alkaloid & Aqueous & Methanolic extract \\
Flavonoid & + & + \\
Saponins & + & + \\
Cardiac glycoside & + & + \\
Tannins & + & + \\
Steroid & + & + \\
Triterpenes & + & + \\
Phenol & + & + \\
Anthraquinones & + & + \\
Carbohydrate & + & + \\
\hline
\end{tabular}

The alkaloids $(84.0 \mathrm{mg} / \mathrm{g})$ was the highest phytochemical detected in the plant while the lowest was saponins $(4.0 \mathrm{mg} / \mathrm{g})($ Table 5$)$.

Table 5: Quantitative Phytochemical screening of methanolic extract of Fadogia agrestis root

\begin{tabular}{ll}
\hline Metabolite & Quantity $(\mathrm{mg} / \mathrm{g})$ \\
\hline Alkaloids & $84.00 \pm 0.57$ \\
Flavonoids & $74.00 \pm 0.29$ \\
Saponins & $4.00 \pm 0.12$ \\
Tannins & $77.00 \pm 0.50$ \\
Phenols & $10.20 \pm 0.51$ \\
\hline
\end{tabular}

No death was recorded in the first phase of the study in rats. In the second phase, doses of 1500, 2250, 3250 and $5000 \mathrm{mg} / \mathrm{kg}$ were used and no death was also recorded (Table 6). The oral median lethal dose (LD50) for the aqueous and methanol root-extract of Fadogia agrestis was therefore estimated to be greater than $5000 \mathrm{mg} / \mathrm{kg}$ and no sign of behavioural changes were also observed.

Table 6: Acute toxicity studies of aqueous extract of Fadogia agrestis root

\begin{tabular}{ccccc}
\hline Plant species & Group & $\begin{array}{c}\text { Number of } \\
\text { Animals }\end{array}$ & Dose $(\mathrm{mg} / \mathrm{kg})$ & $\begin{array}{c}\text { Mortality recorded } \\
\text { after 24hrs }\end{array}$ \\
\hline Phase I & I & 3 & 10 & $0 / 3$ \\
& II & 3 & 100 & $0 / 3$ \\
Phase II & III & 3 & 1000 & $0 / 3$ \\
& I & 1 & 1500 & $0 / 1$ \\
& II & 1 & 2250 & $0 / 1$ \\
& III & 1 & 3250 & $0 / 1$ \\
& IV & 1 & 5000 & $0 / 1$ \\
\hline
\end{tabular}

\section{DISCUSSION}

The studies carried out on the root of Fadogia agrestis have established some pharmacognostic standards that will guide its utilization as crude drug in pharmacy and other fields. These anatomical features of the internal structures of plant drugs provide salient diagnostic characteristics for the identification of both entire and powdered crude drugs and detection of adulterants in plant materials (Ghani, 1990). Macro and microscopical evaluation of crude drugs are targeted at identification of precise variety and search for contaminants in plant materials (WHO, 1996).

Chemo-microscopical examination of the powdered root of Fadogia agrestis revealed the presence of cellulose cell wall, suberized / cuticular cell wall tannins, starch, lignin, calcium oxalate crystals, Suberins, Aleurone grain and gum/mucilage but calcium carbonate was absent (Table 1). The chemo-microscopic features are most valuable in the identification of powdered drug as their identification is largely based on the form, the presence or absence of certain cell types and cell inclusions(Jeremiah et al., 2019). These are very important diagnostic pharmacognostic parameters for the identification and authentication of crude drugs especially in powdered plants (Chanda, 2011). The physicochemical constants of the powdered root of Fadogia agrestis determined include the moisture content, total ash value, acid insoluble ash, water soluble ash, alcohol (ethanol) extractives value and water extractives value (as seen in Table 2). 
BAJOPAS Volume 12 Number 2, December, 2019

These values are useful as criteria to evaluate the identity and purity of crude drugs (Evans, 2009; WHO, 1996). It also indicates the presence of various inorganic materials like carbonate, oxalate and silicate in plant materials. The average moisture content and total ash value of the powdered plant material using loss on drying method was found to be $7.00 \%$ and $10.50 \%$ respectively, this values are within the permissible limits because B. H. P, (1990) and WHO, (2011) recommend the percentage of moisture content in any crude drug to be within 12-14 \% and EP (2011) recommend 10-12\%. Low or permissible moisture in crude drugs may discourage the growth of bacteria, yeast, mould and fungi and will stand for long period of time during storage without spoilage or suggesting better stability against degradation of product (WHO, 1996a).It is very essential to control moisture content since higher moisture content in plant material may lead to deterioration and may therefore result in biodegradation of active constituents. Less moisture content is also an indication that the plant material can be kept for some time (WHO, 2011). Total ash value represent both the physiological and nonphysiological ash from the plant drugs and nonphysiological ash is an indication of inorganic residues after the plant drug is incinerated while acid insoluble ash values of these studies indicated that the plant materials were in good physiological condition and it contained little extraneous matter such as sand, silica, and soil. Total ash value is critical to judge the identity and purity of drugs (WHO, 1996b). A high ash value is indicative of contamination, substitution, adulteration or carelessness in preparing the crude drug for marketing. Water soluble ash is that part of the total ash which is soluble in water. Fadogia agrestis have the water soluble ash and acid insoluble ash value of $8.33 \%$ and $4.10 \%$ respectively. These Ash values indicate the presence of various impurities such as carbonate, oxalate, sand and silicate in plant materials (Kaneria and Chanda, 2011). The acceptable (WHO) limits for total ash and acid insoluble ash vary according to the vegetable drug. Some typical examples include the total ash and acid insoluble ash values of Centella asiatica which should not be more than $19 \%$ and not less than 6\%, respectively (WHO, 1999), similarly, in Pericarpium granati, the total ash should not be more than $4 \%$ and the acid insoluble acid should not be less than $1 \%$ (WHO,2009). The ash value is a measure of the earthy matter orinorganic composition and/or other impurities present along with the drug such as carbonates, phosphates and silicates of sodium, potassium, calcium and magnesium
(Wallis, 2005). The low values of ash in plant materials are indications that these minerals occur only in trace quantities.

The water extractive value and ethanol extractive value of Fadogia agrestis was $12.00 \%$ and $15.00 \%$ respectively (Table 2 ). It was observed that ethanol had a higher extractive value $(15.00 \%)$ than ethanol with extractive value of $12.00 \%$.Despites alcohol's low extraction capacity, it is sometimes more preferred than water especially in researches that deals with natural products because it serves as preservative against microbial growth and easy to evaporate and handle. This is because water is a universal solvent that has high polarity and is able to extract more phytochemical constituents than alcohol that has less polarity. This verified why water is mostly used as solvent by traditional medical practitioner and individuals in preparation of dosage forms (Ajazuddin and Shailendra, 2010). Preliminary phytochemical screening gives a brief idea about the qualitative nature of active phytochemical constituents present in plant extracts, which will helps the future investigators regarding the selection of the particular extract for further investigation or isolating the active principle (Mishra et al., 2010).Preliminary phytochemical screening of the extracts of Fadogia agrestis root revealed the presence of some phytochemicals such as carbohydrate, alkaloids, tannins, flavonoids, cardiac glycosides, saponins, steroids/ triterpenes (Table 4).The information on the presence or absence and the type of phytochemical constituents especially the secondary metabolites are useful taxonomic keys in identifying a particular species and distinguishing it from a related species, thus helping in the delimitation of taxa (Jonathan and Tom, 2008). These secondary metabolites in plants have numerous functions. Crude, pure and isolated alkaloids and their synthetic derivatives have been used as analgesic, antispasmodic and bactericidal agents (Stary, 1998; Okwu and Okwu, 2004). Flavonoids have been shown to provide antibacterial, antiinflammatory, antiallergic, antimutagenic, antiviral, antineoplastic, anti-thrombotic and vasodilatory activity (Alan and Miller, 1996). Flavonoid also has immense antioxidant and anti-inflam-matory activity because of their ability to scavenge hydroxyl radicals, super oxide anions and lipid peroxy radicals (Okwu, 2004; Okwu and Josiah, 2006). Tanins have been used in the treatment of wounds especially those emanating from varicose ulcers and hemorrhoids (Njoku and Akumufula, 2007) and is able to stop bleeding during circumcision (Edeoga et al., 2005). 
BAJOPAS Volume 12 Number 2, December, 2019

Steroids have been reported to have antibacterial and aphrodisiac properties. The presence of steroids in the extracts could support the antibacterial and aphrodisiac properties reported in the literature (Ebana et al., 1991; Cushnie and Lamb, 2005; Akinjogunla et al., 2009). Steroids are very important compound due to their relationships with sex hormones and are useful in the treatment of sexual dysfunction (Oyoedeni and Afolayan, 2011). This makes Fadogia agrestisroot to produce calming effect upon nervous system and there by useful in the treatment of insomnia, anxiety and similar disorders (Robins, 2001). The phytochemical constituents especially the secondary metabolites could be useful as guide to chemotaxonomic markers (Jonathan and Tom, 2008) that will aid in chemo taxonomical classification system and further phylogenetic studies in rubiaceae family.

Concentrations of minerals in Fadogia agrestis root determined by in this study include iron (11.737 ppm), manganese (0.977 ppm) and nickel $(0.223 \mathrm{ppm})$ were below the permissible limit set by FAO/WHO (1984) for edible plants (Table 3). The overall results indicated clearly, the contents of the essential metals such as iron; manganese and nickel were within acceptable limits of the toxic metals such as lead which are within safe limit (Table 3). Therefore, Fadogia agrestis root can also be beneficial sources of appropriate and essential trace elements.

In order to determine the safety margin of drugs and plant products for human use, toxicological evaluation was carried out in experimental animals using Lorke's method to predict toxicity and to provide guidelines for selecting a "safe" dose in animals and also used to estimate the therapeutic index (LD50/ED ${ }_{50}$ ) of drugs (Olson et al., 2000; Rang et al., 2012). In this study, median lethal dose $\left(L_{50}\right)$ of the extracts

\section{REFERENCES}

Ajazuddin, N. and Shailendra, S. (2010). Evaluation of Physicochemical and Phytochemical Properties of Safoof-Esana, a Unani polyherbal Formulation. Journal of Pharmacognosy Research, 2(5): 318-322.

Akinjogula, O.J., Adegoke, A.A., Udokang, I.P and Adebayo-Tayo, B.C. (2009). Antimicrobial potentials of Nymphae lotus (Nymphaceae) against wound pathogens. J.Med. Plants Res.; 3:138141.

Akpabio, U. D., and Ikpe, E. E. (2013): Proximate Composition and Nutrient Analysis of Aneilema aequinoctiale (aqueous and methanol) of the $F$. agrestisroot was carried out orally in rats. The $\mathrm{LD}_{50}$ was found to be greater than $5000 \mathrm{mg} / \mathrm{kg}$ when administered orally in rats (Table 6 ) and all the animals remain alive and did not manifest any significant visible signs of toxicity at these doses. These studies showed the extracts $F$. agrestisroot of are practically non-toxic when administered using the oral route. This is based on the toxicity classification which states that substances with $\mathrm{LD}_{50}$ values of 5000 to 15,000 $\mathrm{mg} / \mathrm{kg}$ body weight are practically non-toxic (Loomis \&Hayes, 1996).

\section{CONCLUSION}

The established pharmacognostic standards for the powder of Fadogia agrestis root could be used as a diagnostic tool for the standardization and identification of this medicinal plant for its purity and quality in the future and hence, inclusion into the pharmacopoeia for official use. Fadogia agrestis root extracts have some secondary metabolites namely alkaloids, tannins, flavonoids, cardiac glycosides, steroids, phenols, triterpenes, anthraquinones and saponins. These contribute in the effect of the plant. The Acute toxicity $\left(L D_{50}\right)$ of the root extracts of Fadogia agrestis (water) was found to be greater than $5000 \mathrm{mg} / \mathrm{kg}$ and is considered safe for use.

\section{RECOMMENDATION}

Pharmacognostic parameters of other plant parts should be established for inclusion to aids standardization for quality, purity and identification and for possible inclusion into official book. Chronic toxicity study of Fadogia agrestis root extracts should be carried out to establish its safety in long time use. Isolation and characterization of compound(s) from Fadogia agrestis root extracts should be carried out.

leaves. Pelagia Research Library. Asian Journal of Plant Science and Research, 3(2):55-61.

Alan, L. and Miller N.D. (1996). Antioxidant Flavonoids: Structure, Function and Clinical Usage. Alternative Medicine Rev., 1: 103-111.

Association of Organic and Analytical Chemistry (2000). Official methods of analysis 19th Edition. Association of Official Analytical Chemists, Washington, DC, US.

Association of Organic and Analytical Chemistry (2005). Official methods of analysis 20th edition. Association of Official Analytical Chemists, Washington, DC, USA. 
BAJOPAS Volume 12 Number 2, December, 2019

Bohm, B. A. and Kocipal-abyazan, R. (1994). Flavonoids and Condensed tannins from leaves of Vaccinumv aticulatum and $V$. calycinium, Pacific Journal of Sci. 48: 458-463.

British Herbal Pharmacopoeia (1990). British Herbal Medicine Association. Bournemouth:

Dorset. 1st edition. Vol.1. Pp. 1 -2.

Chanda, S. (2011). Importance of Pharmacognostic Study of Medicinal Plants: An Overview. Journal of pharmacognosy and phytochemistry, 2 (5), 503-514.

Chin, Y.W., Balunas, M. J., Chai, H. B., and Kinghorn, A. D. (2006). "Drug Discovery from Natural Sources," The American Association of Pharmaceutical Scientists Journal, 8 (2), 239-242.

Cushine, T.P. and Lamb, A.J.(2005). Antimicrobial activity of flavonoids. Int. J. Antimicrob. Agents. 26: 343-356.

Ebana, R.U., Madunagu, E.D., Ekpe, O., Otung, I.N.(1991). Microbial exploitation of cardiac glycosides and alkaloids from Garcinia kola, Borreria ocymoides and Kola nitida.J. Applied Microbiology. 71: 398-401.

Edeoga, H.O., Okwu, D.E. and Mbaebie, B.O. (2005). Phytochemical constituents of some Nigerian Medicinal plants. African Journal of Biotechnology, 4: 685-688.

Evans, W. C. (2002). Trease and Evans Pharmacognosy. 15th (ed.) Saunders Publishers, an imprint of Elsevier Science Ltd. India. Pp. 42-44, 221-229, 246-249, 304-306, 331-332, 391-39.

Evans, W.C (2009). Trease and Evans' Pharmacognosy, 16th Edition. Saunders Elsevier Toronto, Canada. pp. 1-9, 26, 225, 252, 304, 356, 437-440.

FAO/WHO (2004). Vitamin and Mineral Requirements in Human Nutrition. Joint FAO/WHO Expert Consultation on Human Vitamin and Mineral Requirements (1998: Bangkok, Thailand). ISBN 9241546123 (LC/NLM Classification: QU 145).

Food and Agricultural Organization/World Health Organization (FAO/WHO) (1984). Contaminants. In Codex Alimentarius, vol. XVII, Edition 1. FAO/WHO, Codex Alimentarius Commision, Rome.

Ghani, A. (1990). Introduction to Pharmacognosy. Ahmadu Bello University, Press Ltd. 1st Edition, Pp187.

Harborne, J.B. (1973). Phytochemical Methods, Chapman and Hall limited. London, 49 $-68$.
Harborne, Z. B. (2009). Phytochemical methods: A guide to modern techniques of plant analysis, 3rd edn. Chapman and Hall Press, London. Pp. 13, 53, 53 195, 283.

Haslam E. (1996). "Natural polyphenols (vegetable tannins) as drugs: possible modes action," Journal of Natural Products, 59(2): 205-215.

Jeremiah, C., Katsayal, U.A., Nuhu, A., Nuhu, H.D.(2019). Pharmacognostic and Elemental Analysis of the Leaves of Tapinanthus globiferus (A. Rich). Tiegh. Res J Pharmacogn; 6(1): $11-18$.

Jonathan, G. and Tom J. M. (2008).Secondary metabolites and the higher classification of angiosperms. Dept of Botany, Univ. of Texas, Austin, TX 78712, USA. Nordic Journal of Botany 3(1):5 - 34.

Kaneria, M., and Chanda, S. (2011). Phytochemical and Pharmacognostic Evaluation of the Leaves of Psidium guajava L (Mrytaceae). Journal of Pharmacognosy; 3 (23): 41-45.

Loomis, T.A and Hayes, A.W.(1996). Loomis Essentials of Toxicology. (4th ed.). California, U.SA: Academic Press; 208$245 \mathrm{p}$.

Lorke, D. (1983). A new approach to practical acute toxicity testing. Archives ofToxicology, 54 (4): 275-287.

Mishra, S. B., Mukerjee, A and Vijayakumar, M. (2010). Pharmacognostical and Phytochemical Evaluation of Leaves Extract of Jatropha curcus Linn. Journal of Pharmacognosy. 2:9-14.

Njoku, P.C. and Akumufula, M.I. (2007).Phytochemical and nutrient evaluation of spondias mombi Leave. Pakistani Journal of Nutrition, 6(6):613615.

Obadoni, B. O and Ochuko, K. (2001). Phytochemical studies and comparative efficacy of the crude extract of some haemostatic plants in Edo and Delta States. Global Journal of Pure and Applied Science, 8:203-208.

Okwu, D.E and Josiah, C. (2006). Evaluation of the chemical composition of two Nigerian medicinal plants. African Journal of Biotechnology, 5(4): 357-361.

Okwu, D.E. (2004). Phytochemicals and vitamin content of indigenous spices of Southeastern Nigeria. Journal of Sustain. Agricultural Environment, 6(1): 30- 37.

Okwu, D.E. and Okwu, M.E. (2004).Chemical composition of Spondias mombin linn plant parts. Journal of Sustain. Agricultural Environment, 6(2): 140-147. 
BAJOPAS Volume 12 Number 2, December, 2019

Olson, H., Betton, G., Robinson, D., Thomas, K., Monro, A., Kolaja, G., Lilly, P., Sanders, J., Sipes, G., Bracken, W., Dorato, M., Deun, K.V., Smith, P., Berger, B and Heller, A.(2000). Concordance of Toxicity of Pharmaceuticals in Humans and in Animals. Regul Toxicol Pharmacol., 32: 56-67

Oyodeni, S.O and Afolayan, A.J. (2011). Antibacterial and antioxidant activities of hydrochloric stem extract of Schotia latifoliaAsian Pac. J. Trop. Med; 4:70-78.

Patwardhan, B., Vaidya, A. D. B., and Chorghade, M. (2004) "Ayurveda and Natural Products Drug Discovery," Current Science, 86(6), 789-799.

Rang, H.P., Dale, M.M., Ritter, J.M., Flower, R.J., Henderson, G.(2012). Rang and Dale's pharmacology. (7th ed.). London: Churchill Livingstone; 377 p.

Robins, D.(2001). Nymphae odorata (White pond lily) in medical Herbalism. Mater. Med. Pharm., 11: 231-233.
Stary, F. (1998). The Natural Guide to Medicinal Herbs and Plants. Tiger Books International, London pp. 12-16.

Van-burden, T. P and Robinson, W. C. (1981). Formation of Complexes between protein and Tannic acid. Journal of Agriculture Food Chemistry. 1:77

Wallis, T.E. (2005). Textbook of Pharmacognosy. 5th ed. New Delhi: CBS publisher \& Distributors; P 561.

World Health Organization (2011). Quality Control Methods for Medicinal Plants. WHO, Geneva, Switzerland, Pp. 31.

World Health Organization. (WHO).( (1996b). Guidelines for the Assessment of Herbal Medicines. WHO Technical Report Series, World Health Organization, Geneva. 863.

World Health Organization. (WHO).(1996a). Quality Assurance of Pharmaceuticals: A Compendium of Guidelines and Related Materials, Good Manufacturing Practices and Inspection. World Health Organization, Geneva. 2. 